\title{
Wegener-granulomatosis talaján kialakult krónikus gennyes középfülgyulladás komplex kezelése
}

\author{
Tóth István dr. ${ }^{1}$ - Kaszás Bálint dr. ${ }^{2}$ - Horváth Gábor dr. ${ }^{3}$ \\ Piski Zalán dr. ${ }^{1}$ - Bakó Péter dr. ${ }^{1}$. Lujber László dr. ${ }^{1}$ \\ Gerlinger Imre dr. ${ }^{1}$ - Révész Péter dr. ${ }^{1}$ \\ ${ }^{1}$ Pécsi Tudományegyetem, Általános Orvostudományi Kar, Klinikai Központ, \\ Fül-Orr-Gégészeti és Fej-Nyaksebészeti Klinika, Pécs \\ ${ }^{2}$ Pécsi Tudományegyetem, Általános Orvostudományi Kar, Klinikai Központ, Pathologiai Intézet, Pécs \\ ${ }^{3}$ Pécsi Tudományegyetem, Általános Orvostudományi Kar, Klinikai Központ, \\ Reumatológiai és Immunológiai Klinika, Pécs
}

\begin{abstract}
A Wegener-granulomatosis - újabb nevén polyangitis granulomatosis - súlyos, antineutrofil citoplazmatikus antitest asszociálta, kis ereket érintő vasculitis, melyet a légúti traktus és a renalis rendszer nekrotizáló, granulomatosus gyulladása jellemez. A fülészeti manifesztációk a kórkép korai fázisában fordulhatnak elő, melyek közül a leggyakrabban savós középfülgyulladás, maszkolt otomastoiditis, esetenként sensorineuralis halláscsökkenés jelentkezhet. A diagnózis felállítása a klinikai képen, az immunszerológiai, valamint a hisztopatológiai vizsgálatokon alapszik. A kombinált immunszuppresszív terápia mellett a lokális manifesztációk szanálása szükséges. A terápiarezisztens, Wegener-granulomatosis talaján kialakult elhúzódó középfülgyulladás gyakran komoly kihívás elé állítja a fül-orr-gégészt. Ilyen esetekben a felkészült fülsebész kezében stabil megoldást jelent a subtotalis petrosectomia, amellyel zárt, reakciómentes középfül kerül kialakításra, s abban szimultán vagy halasztottan végezhető hallásrehabilitáció modern, implantálható hallásjavító készülékekkel. A jelen közleményben a szerző́k áttekintik a vonatkozó irodalmat és egy esetbemutatáson keresztül ismertetik a Wegener-granulomatosis fülészeti megjelenésének komplex ellátását a modern szakmai szemlélet jegyében.

Orv Hetil. 2019; 160(4): 151-157.
\end{abstract}

Kulcsszavak: polyangitis granulomatosis, halláscsökkenés, cochlearis implantáció

\section{Modern management of otologic consequences of Wegener's granulomatosis - a case report and review of the literature}

Wegener's granulomatosis - or, in other words, granulomatosis with polyangiitis - is an anti-neutrophil cytoplasmic antibody associated granuloma forming vasculitis, mainly affecting the respiratory tract and the renal system. Otologic manifestations of Wegener's disease can be otitis media with effusion or chronic silent mastoiditis with conductive hearing loss, but sensorineural hearing loss can also evolve. The diagnosis is based on the clinical appearance as well as the immunoserological and histopathological results. It is of paramount importance to begin a combined immunosuppressive treatment immediately, besides eradicating the otologic manifestations. The intractable cases of chronic otitis media due to Wegener's granulomatosis are challenging any ear surgeons. Subtotal petrosectomy has proved to be an effective solution in such cases to create a dry ear and to provide a safe surgical field for hearing restoration. The authors reviewed the literature and report a case history to present the modern management of Wegener's granulomatosis with otologic manifestation.

Keywords: granulomatosis with polyangiitis, hearing loss, cochlear implant

Tóth I, Kaszás B, Horváth G, Piski Z, Bakó P, Lujber L, Gerlinger I, Révész P. [Modern management of otologic consequences of Wegener's granulomatosis. Case report]. Orv Hetil. 2019; 160(4): 151-157.

(Beérkezett: 2018. augusztus 1.; elfogadva: 2018. szeptember 3.) 


\section{Rövidítések}

ANCA $=$ antineutrofil citoplazmatikus antitest; CD20 = (cluster of differentiation) a jelen esetben a B-sejtekre jellemző, monoklonális antitesttel kimutatható molekula; $\mathrm{CT}=($ computed tomography) számítógépes tomográfia; $\mathrm{dB}=$ decibel; HIV = humán immundeficientiavírus; HRCT $=($ high-resolution CT $)$ nagy felbontású CT; $\mathrm{MPO}=$ mieloperoxidáz; $\mathrm{MPO}-\mathrm{ANCA}=$ mieloperoxidáz ellen termelt antineutrofil citoplazmatikus antitest; $\mathrm{MRI}=$ (magnetic resonance imaging) mágnesesrezonancia-képalkotás; OMAAV = antineutrofil citoplazmatikus antitest asszociálta polyangitises otitis media; PR3 = proteináz-3; PR3-ANCA = proteináz-3 ellen termelt antineutrofil citoplazmatikus antitest; PTE = Pécsi Tudományegyetem; PTE KK = Pécsi Tudományegyetem, Klinikai Központ; TSH = thyreoideastimuláló hormon

A Wegener-granulomatosis - újabb nevén polyangitis granulomatosis - egyike a súlyos, antineutrofil citoplazmatikus antitest (ANCA) asszociálta, kis ereket érintő vasculitiseknek. A kórképet kezdetben granulomatosus elváltozások jellemzik elsősorban a felső és alsó légutakban, illetve az esetek nagy részében rapidan progrediálódó glomerulonephritis is jelentkezhet [1]. A legújabb közlemények külön entitásként jelölik meg az ANCAasszociált vasculitisekhez társult középfülgyulladást (OMAAV) [2].

A betegség incidenciája 10-20/1 000000 lakos évente, és a leggyakrabban a kaukázusi népcsoport érintett [3]. A Wegener-granulomatosis bármelyik korcsoportban elófordulhat nemi predominancia nélkül [3], az ANCAasszociált polyangitises otitis media (OMAAV) esetén azonban 73\%-os női predominanciát állapított meg egy japán közlemény 235 eset alapján [4]. A betegség a leggyakrabban 40 és 65 év között jelenik meg, míg a gyermekkori manifesztáció rendkívül ritka [1]. Bár etiológiája és patofiziológiája nem tisztázott, feltehetően genetikailag prediszponált egyénekben alakul ki infektológiai és környezeti faktorok hatására. A Wegener-granulomatosis patogenezisében az esetek 80\%-ában proteináz-3 (PR3) ellen képződött antineutrofil citoplazmatikus antitest jelenléte figyelhetố meg [3], míg OMAAV esetén gyakrabban fordul elő mieloperoxidáz (MPO)-ANCA-pozitivitás $[2,4]$. A kezdeti stádiumban nem specifikus tüneteket (fáradékonyság, végtagi fájdalom, fogyás, láz) követôen jelentkeznek a bőr- és nyálkahártya-elváltozások, fül-orrgégészeti laesiók; visszatérő gennyes középfülgyulladások, orrvérzés, -pörkösödés, szájnyálkahártya-fekélyek, subglotticus stenosis, vezetéses és/vagy idegi jellegú halláscsökkenés. A felsoroltak mellett az alsó légutak érintettsége szintén gyakori; köhögés, véres köpet, kavitálódó tüdőgócok, pulmonalis bevérzések jellemzőek. A generalizált betegség részeként renalis eltérések, cardiovascularis laesiók, központi idegrendszeri manifesztációk jelenhetnek meg $[3,5,6]$. A diagnózis felállítása a klinikai képen, immunszerológiai és szövettani vizsgálaton alapszik. A lokális manifesztációk szanálása mellett kombinált immunszuppresszív terápia bevezetése szükséges. A beveze- tő kezelés általában kortikoszteroid és ciklofoszfamid adását jelenti, majd a remisszió fenntartására metotrexát vagy azatioprin adása javasolt. Új terápiás opció a B-sejtek CD20 markere elleni monoklonális antitest, a rituximab alkalmazása. Az adekvát kezelés mellett több mint 90\%os remissziós arány érhetố el [3].

A Wegener-granulomatosis talaján azonban jelentkezhet terápiarezisztens, elhúzódó középfülgyulladás, illetve nagyfokú, maradandó idegi halláscsökkenés is, melyek megoldása komoly kihívás elé állítja a gyakorló fül-orrgégészt $[5,6]$. A konzervatív kezelésre és limitált mútéti beavatkozásokra (mastoidectomia, tympanoplastica) nem javuló fülészeti status esetén subtotalis petrosectomia a javasolható mútéti megoldás egy zárt, reakciómentes középfül kialakításához, lehetőséget teremtve a hallás rehabilitálására is. A mútét a temporalis csont sejtrendszerének teljes exenterációját jelenti a külső hallójárat és a fülkürt lezárásával [7]. Közleményünkben egy középkorú nőbeteg esetében mutatjuk be a kórkép fülészeti manifesztációját, valamint ennek megoldását a modern szakmai szemlélet jegyében.

\section{Esetismertetés}

Egy 56 éves nőbetegünknél 2016 nyarán kétoldali genynyes középfülgyulladást diagnosztizáltak egy másik intézet szakrendelésén. Több ciklus per os antibiotikumkezelés és kétoldali paracentesis ellenére tünetei perzisztáltak. A PTE Fül-Orr-Gégészeti és Fej-Nyaksebészeti Klinikájára 2016 szeptemberében progrediáló állapota miatt került felvételre. Szédülékenység, hányinger, fülfolyás, kétoldali közepes fokú vezetéses típusú halláscsökkenés mellett a részletes anamnézisfelvétel fél éve fennálló kisízületi fájdalomra, fáradékonyságra, szemszárazságra derített fényt. Korábbi laborparamétereiból magasabb TSH-szintje tûnt ki. Endokrinológiai konzílium alapján véleményezett Hashimoto-thyreoiditis miatt szubsztitúciós terápiát indítottak. A páciens progrediáló tüneteire való tekintettel koponya-CT készült, amely jobb oldali maszkolt otomastoiditis klinikai diagnózisát erősítette meg (1. ábra), emiatt 2016. szeptember 23-án jobb ol-

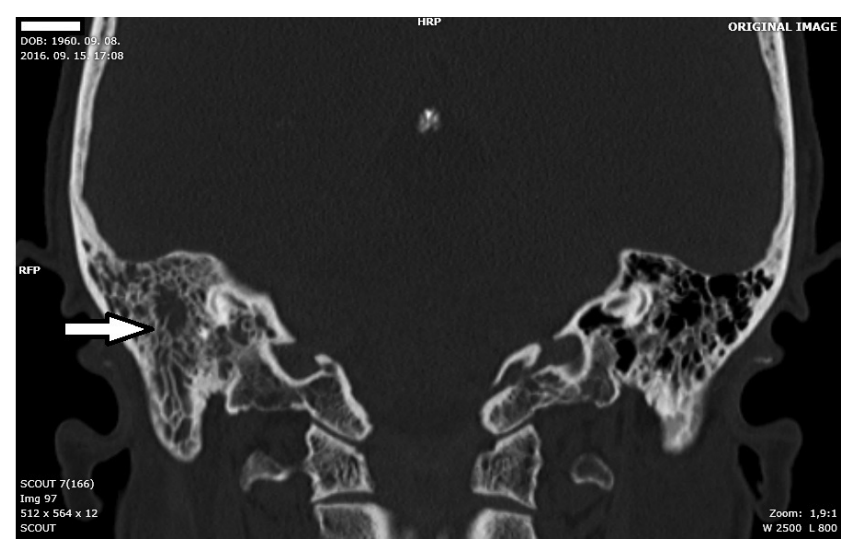

\begin{tabular}{l|l} 
1. ábra & A nagy felbontású CT (HRCT) képen a jobb oldali processus
\end{tabular} mastoideus fedettsége látható (nyíl) 


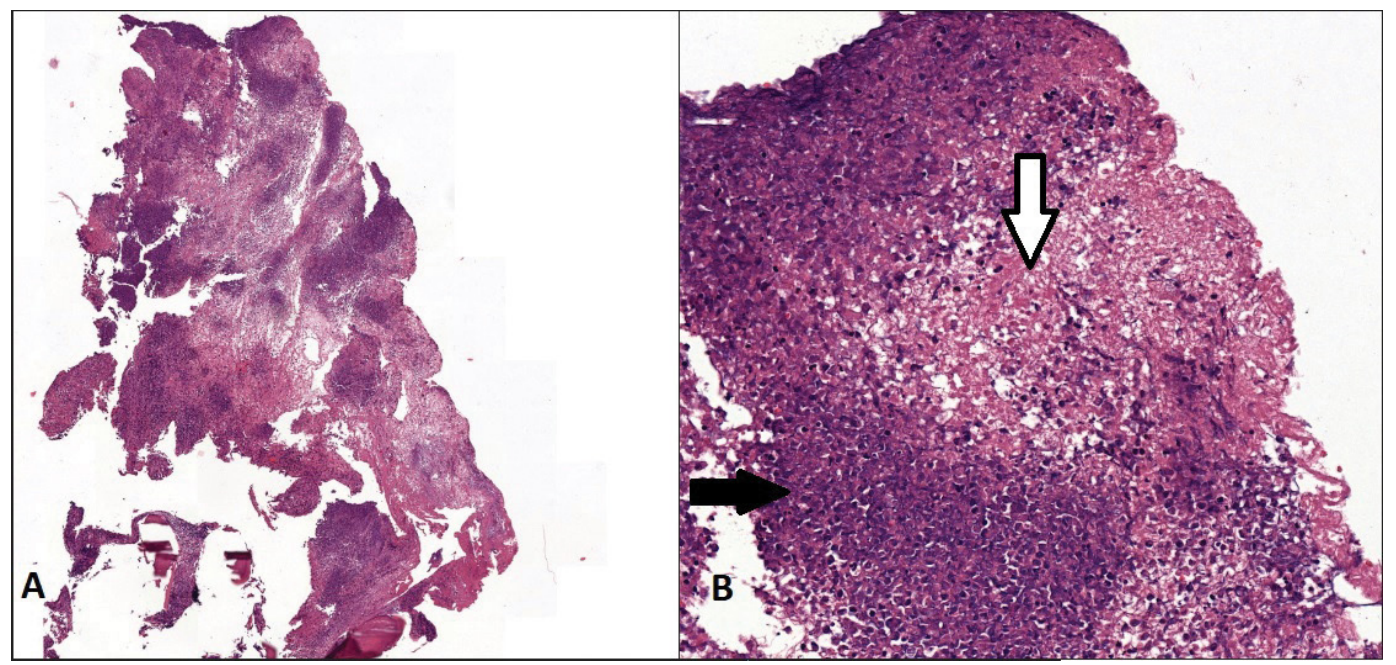

2. ábra

\begin{abstract}
A 2016. 10. 23-án végzett bal oldali mastoidectomia során az antrum területéről eltávolított szövet hisztológiai vizsgálata Wegener-granulomatosist igazolt $(A, H E, 4 \times)$. Az eozinofil festődésű terület nekrózisra (fehér nyíl), míg a bazofil festődésű terület az abszcedáló, granulomatosus gyulladásra jellemző epitheloid makrofágokra utal (fekete nyíl) $(B, H E, 20 \times)$

$\mathrm{HE}=$ hematoxilin-eozin festés
\end{abstract}

dali mastoidectomiát végeztünk (op. dr. Lujber). A posztoperatív 7. napon a páciensnél jobb oldali HouseBrackmann III/VI-os facialis paresis alakult ki. A perzisztáló jobb oldali fülfolyás és erős fejfájás miatt kért neurológiai vizsgálat a meningitist kizárta, a kontrollsziklacsont-HRCT azonban a processus mastoideus néhány sejtjében további fedettséget mutatott, emiatt alapos, kiterjesztett mastoidectomia elvégzése mellett döntöttünk (op. dr. Lujber). A remittáló bal oldali középfülgyulladás miatt egy ülésben széles bal oldali paracentesist is végeztünk. Tekintettel a terápiarezisztens, makacs középfülgyulladásra, felmerült immunológiai betegség lehetősége, azonban az ekkor kért immunológiai konzílium és immunszerológiai vizsgálatok ezt kizárták. A fülváladék mikrobiológiai vizsgálata Achromobacter xylosoxidanst igazolt, melyre célzott antibiotikumterápiát indítottunk infektológussal történt egyeztetést követően (piperacillin/tazobaktám napi $3 \times 1 \mathrm{~g}$, majd meropenem napi $3 \times 1 \mathrm{~g})$. A stagnáló klinikai kép miatt antifungalis kezelést is bevezettünk (flukonazol $200 \mathrm{mg}$ napi dózisban). Egy hónappal később a betegnél ismételten egyensúlyzavar, szédülés jelentkezett. Vestibularis vizsgálatainkkal a labyrinthus funkcióvesztését kizártuk, az intracranialis szövődmény irányában a kért koponyaMRI sem mutatott kóros eltérést. Ismételt osztályos obszervációnk során a páciens halláscsökkenése fokozódott, az arcidegbénulás bilaterálissá vált és tovább romlott. A koponya-CT bal oldali mastoid fedettséget mutatott, emiatt a klinikai képre alapozva bal oldali mastoidectomiát végeztünk (op. dr. Bakó). A mastoid üregból vett szövettani minta vizsgálata granulomatosus gyulladást igazolt (leletszám: 14541-2016). A klinikai kép alapján differenciáldiagnosztikai szempontból immunhiány, autoimmun vasculitis, neoplasia merült fel, a HIV-szerológia negatív volt. A nyaki és hasi ultrahang nem mutatott kóros eltérést. A mellkas-CT kétoldali infiltratív gócot írt le a tüdőkben, melyek vonatkozásában a bronchoszkópos vizsgálat a malignitást kizárta. A liquorvizsgálat, koponya-MR továbbra is negatív eredményt hozott. Az immunszerológiai vizsgálat azonban a proteináz-3 antineutrofil citoplazmatikus antitest (PR3-ANCA) emelt szintjét igazolta, így az ezt követően történt ismételt patológiai konzultáció (leletszám: 14541-2016, 2. ábra) és a klinikai adatok alátámasztották a Wegener-granulomatosis diagnózisát.

A beteget a PTE Reumatológiai és Immunológiai Klinikájára irányítottuk, ahol metilprednizolon és ciklofoszfamid alkalmazásával immunszuppresszív terápia kezdődött. Az elkövetkező három hónapban panaszai jelentősen regrediáltak, a bakteriológiai vizsgálatok negatívnak bizonyultak. A páciens hallása és mindkét oldali arcidegfunkciója javult, a metilprednizolon dózisát folyamatosan csökkentették.

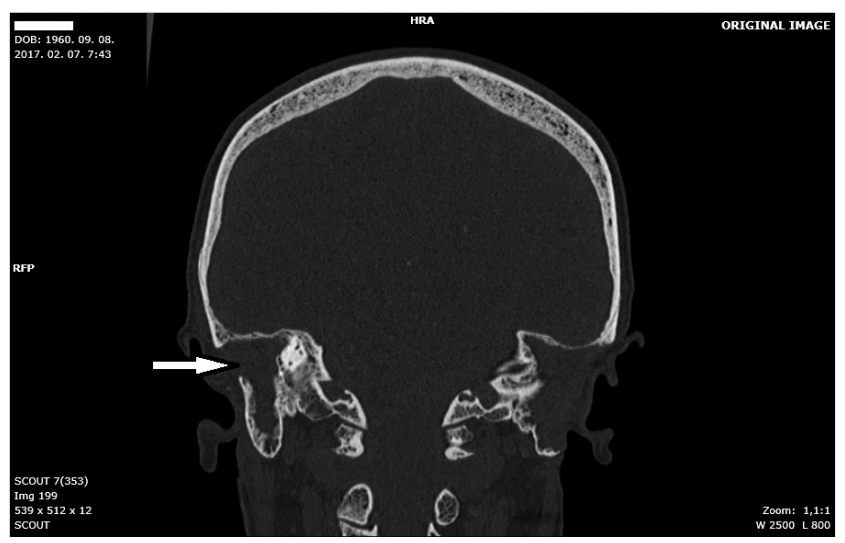

3. ábra $\quad$ A jobb oldali subtotalis petrosectomiát megelőzően készült CTfelvételen a továbbra is váladékozó jobb oldali mastoid üreg látható (nyíl) 


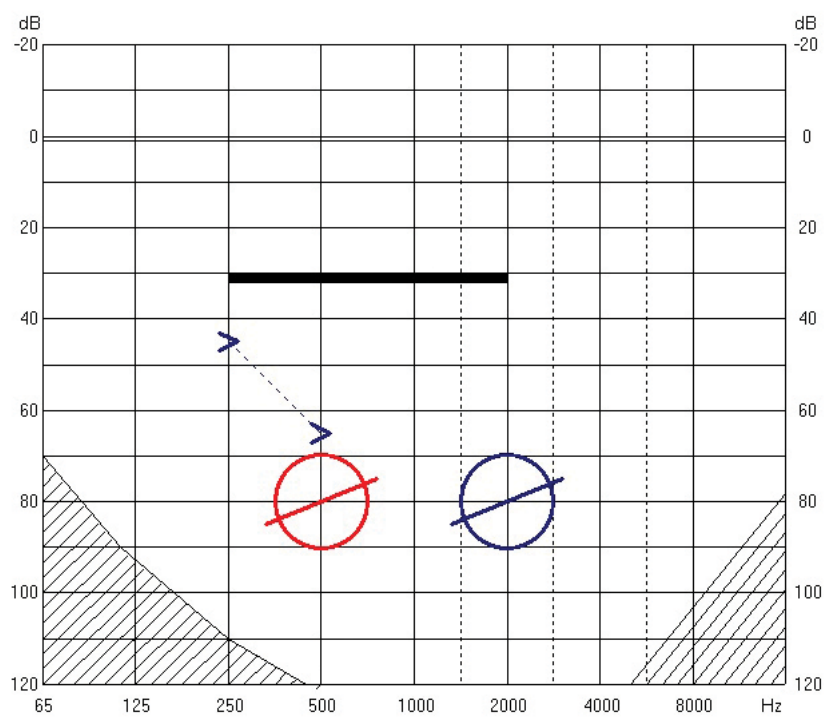

4. ábra

A subtotalis petrosectomiát megelőzően készült összevon audiogram, amely mindkét fülre vonatkozik. Hallás egyik oldalon sem mutatható ki (piros szín: jobb oldal; kék szín: bal oldal)

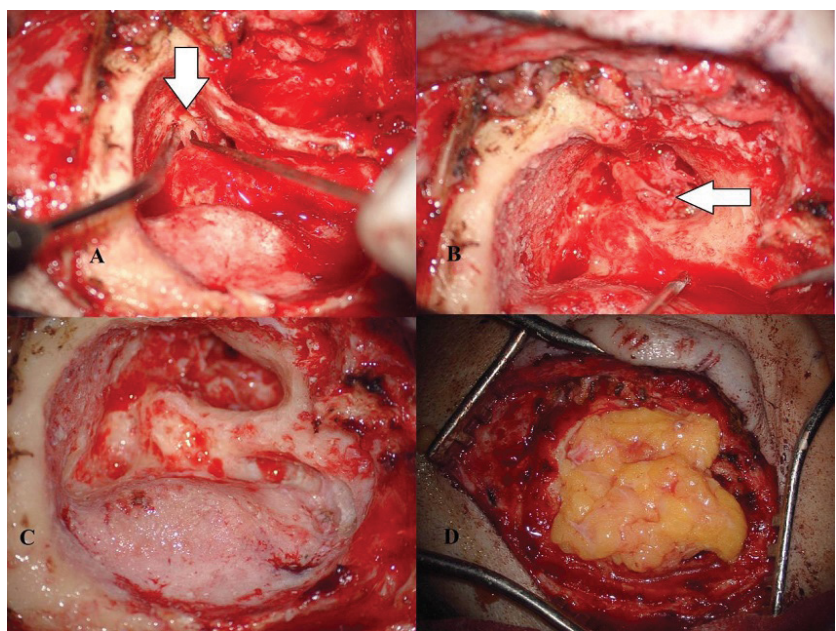

5. ábra

A korábbi mastoidectomia ürege, az incus környékén gyulladt nyálkahártya (nyíl) (A). Eltávolított hátsó hallójáratfal mellett jól látható a dobüreget kitöltő szövetplusz (nyíl) (B). A subtotalis petrosectomia komplettált csontmunkával (C). A subtotalis petrosectomia ürege hasi zsírral obliterálva $(D)$

A páciensnél 2017 februárjában a harmadik ciklofoszfamidkezelés ellenére ismételten forgó jellegű szédülés jelentkezett, melynek hátterében jobb oldali akut vestibularis kiesést igazoltunk. A koponya-CT intracranialisan továbbra sem mutatott kóros eltérést (3. ábra). Immunológiai javaslatra emeltünk (16 mg) a per os szteroid dózisán, illetve az emelkedett gyulladásos laborparaméterek miatt ex juvantibus antibiotikumterápiát indítottunk (amoxicillin/klavulánsav $3 \times 1,2 \mathrm{~g}$ ). Mindkét oldali fülváladékból Achromobacter xylosoxidans tenyészett ki. A kért immunológiai szakvélemény a ciklofoszfamidkezelést eredménytelennek ítélte, ehelyett rituximabkezelést indítottak. A negyedik ciklus immunszuppresszív terápia ellenére a betegnél hallást regisztrálni nem tud-

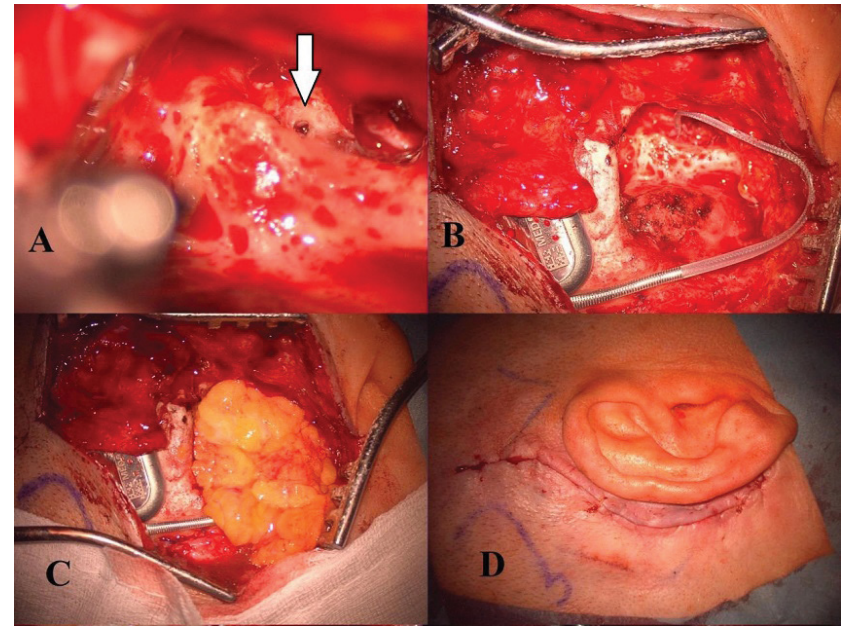

6. ábra

A subtotalis petrosectomia üregében végzett cochleostomia (nyíl) (A). A cochleostomába bevezetett elektróda. Az elektródát a kerekablak hozzáférhetetlensége miatt cochleostomán keresztül sikerült bevezetni $(B)$. A subtotalis petrosectomia üregét frissen vett hasi zsírral obliteráljuk $(C)$. Intracutan varrattal zárt mútéti terület $(D)$

tunk, szédülése is változatlanul fennállt (4. ábra). Tekintettel a jobb oldali vestibulocochlearis funkcióvesztésre, a folyamatosan fennálló, terápiarezisztens fülfolyásra, valamint az opportunista kórokozó jelenlétére, jobb oldali subtotalis petrosectomia mellett döntöttünk.

Megfelelő előkészítést követően a beavatkozást 2017. május 29-én végeztük el, melynek során a külső hallójáratot lezártuk, a középfül üregrendszerét érintő gyulladt nyálkahártyát eltávolítottuk, a retrofacialis, retrosigmoid, pericarotidealis, supratubaris és hypotympanalis sejteket elvettük. A fülkürtöt izomdarabbal, míg a mútéti területet hasi zsírral obliteráltuk (op. dr. Révész, 5. ábra). A dobüregből eltávolított gyulladt sarjszövet szövettani vizsgálata specifikus folyamatot nem igazolt (leletszám: 06991-2017). A mútétet követően 1 hónappal a javuló klinikai kép és normális laborparaméterek miatt a páciensnél fenntartó dózisú metotrexát bevezetését kezdtük el, a szisztémás szteroid dózisát csökkentettük. A havonta történő immunológiai vizsgálat a kezelés hatékonyságát igazolta, a beteg panaszmentes volt, a laborvizsgálatok során nem találtunk eltérést.

A remisszióban lévő Wegener-granulomatosis, illetve a gyulladásmentes fülstatus miatt a tervezett jobb oldali cochlearis implantációra a subtotalis petrosectomiát követôen fél évvel került sor, mely sikeresnek bizonyult (op. dr. Révész, 6. ábra). Ezt követően a rituximabkezelést megismételtük, a metilprednizolont tovább csökkentettük, majd fokozatosan elhagytuk. Jelenleg a páciens fenntartó metotrexátkezelése folyik. A terápia mellett a beteg állapota és mindkét oldali arcidegfunkciója jelentősen javult, a cochlearis implantációt követően 2 hónappal mindkét oldalon House-Brackmann II/VI-os funkciót regisztráltunk (7. ábra). Bekapcsolt készülékkel a beszédfrekvenciák átlagán mért hallásküszöb 2018 márciusában a 4. posztoperatív beállítás so- 


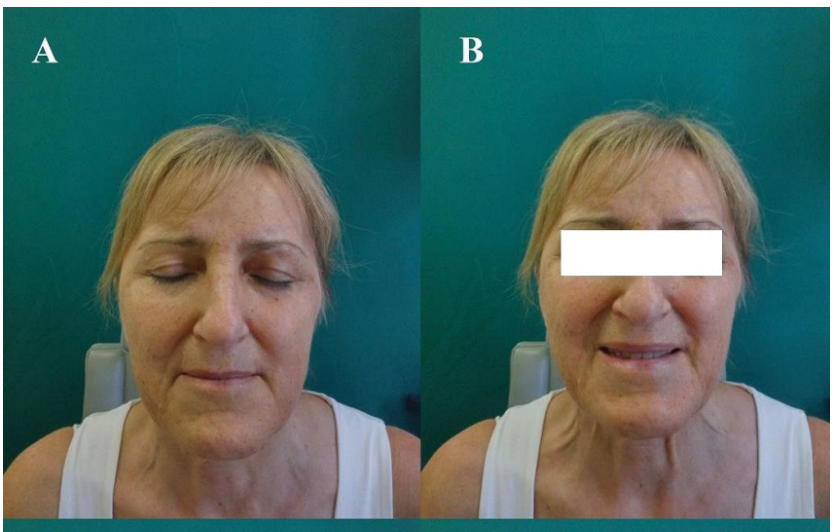

C D

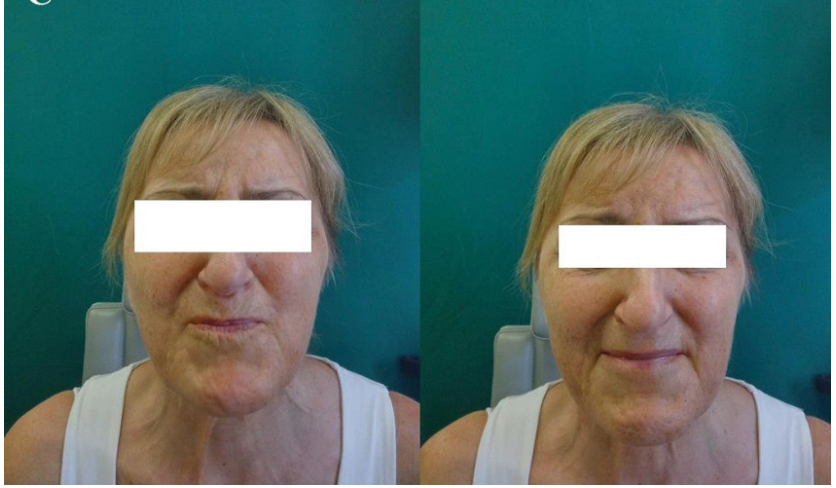

7. ábra

A subtotalis petrosectomiát követően 2 hónappal észlelt facialis funkció; szemzárás $(A)$; fogmutatás $(B)$; csücsörítés $(C)$; hom lokráncolás $(D)$

rán 43,75 dB volt (8. és 9. ábra). A páciens állapota azóta is stabil, a mútéti terület reakciómentes mindkét oldalon.

\section{Megbeszélés}

A Wegener-granulomatosis a leggyakrabban a légúti traktust és a renalis rendszert érintő, nekrotizáló, granulomatosus gyulladással járó kórkép [1]. A fül-orr-gégé-

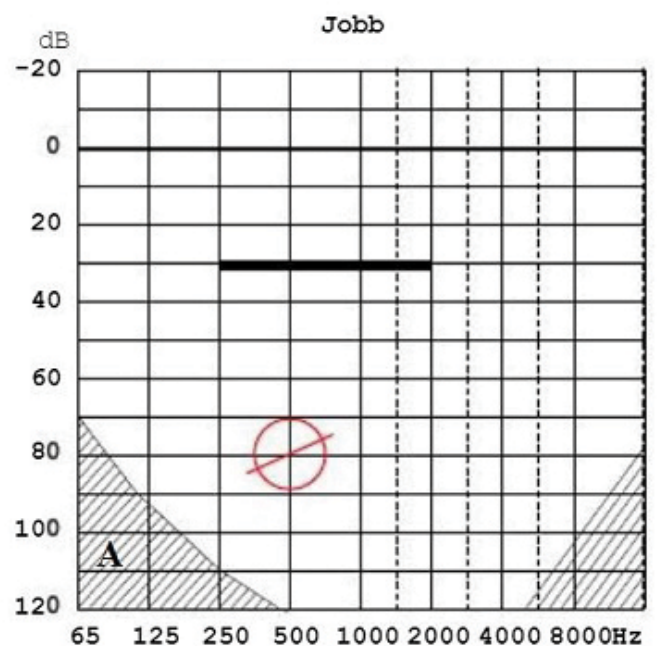

szeti manifesztációk közül a savós középfülgyulladás, a maszkolt otomastoiditis és a sensorineuralis halláscsökkenés jellemző $[5,6]$.

A subtotalis petrosectomia technikája már az 1950-es években bemutatásra került, azonban a fogalmat elsőként Ugo Fisch használta 1965-ben [8]. Ez a technika megoldást kínál a krónikus, rekurráló középfülgyulladások szanálására, illetve újabban sikeresen alkalmazzák a középfül üregrendszerét érintő paragangliomák eltávolítására is [9]. A subtotalis petrosectomia előnye, hogy száraz, reakciómentes mútéti területet eredményez, ami a hallásrehabilitáció szempontjából előnyös [7, 9]. Prasad és mtsai hangsúlyozzák, hogy a precízen operált subtotalis petrosectomia mellett egy időben elvégezhető a cochlearis implantáció, és csak kétséges szanáció esetében szükséges halasztott implantáció mellett dönteni [9]. Hasonló az álláspontja Szymańskinak és munkatársainak is, akik 14 esetben végeztek szimultán, 5 esetben pedig halasztott subtotalis petrosectomiát és cochlearis implantációt. A kétüléses beavatkozást mindig a gyógyszeres kezelésre nem reagáló bakteriális infekció okozta gyulladás esetén végezték. A betegség szanálását követően mind a 19 esetben sikeres hallásrehabilitációt értek el [7].

Esetünkben a teljes vestibulocochlearis kiesés, valamint a többszöri mastoidectomiára, célzott antibiotikus terápiára és a megkezdett kétféle immunszuppresszív kezelés ellenére sem gyógyuló, a középfül üregrendszerét érintő specifikus gyulladás miatt végeztünk subtotalis petrosectomiát. A mútétet megelőzően a Gram-negatív, opportunista Achromobacter xylosoxidanst célzott gyógyszeres terápiával nem sikerült eradikálni. Egy tanulmány az Achromobacter xylosoxidans okozta rekurráló, szeptikus arthritis kapcsán hangsúlyozta a kombinatív mütéti és konzervatív terápia szükségességét, amely végül sikeres kezelésnek bizonyult [10]. Esetünkben az immunszuppresszív kezelés mellett várható magasabb morbiditási ráta miatt döntöttünk második ülésben végzett cochlearis implantáció mellett.

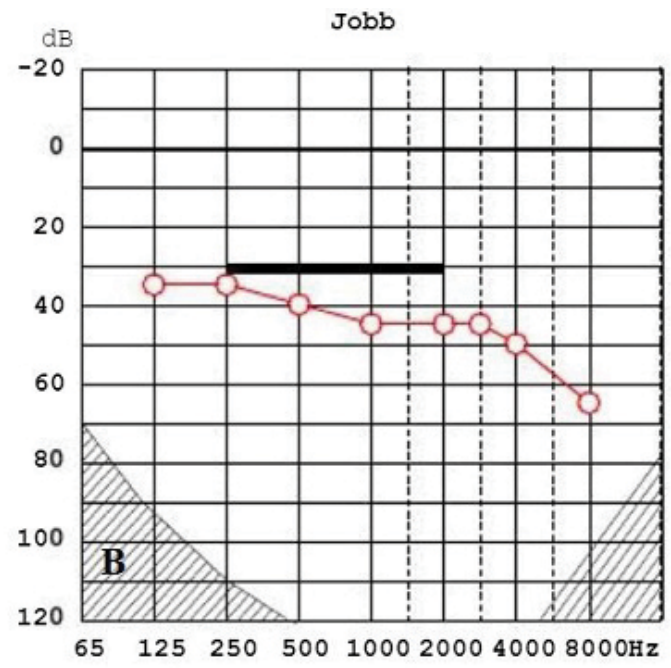

8. ábra | Preoperatíve mért siketség $(A)$. A cochlearis implantációt követő 4 . beállítás során regisztrált audiogram $(B)$ 

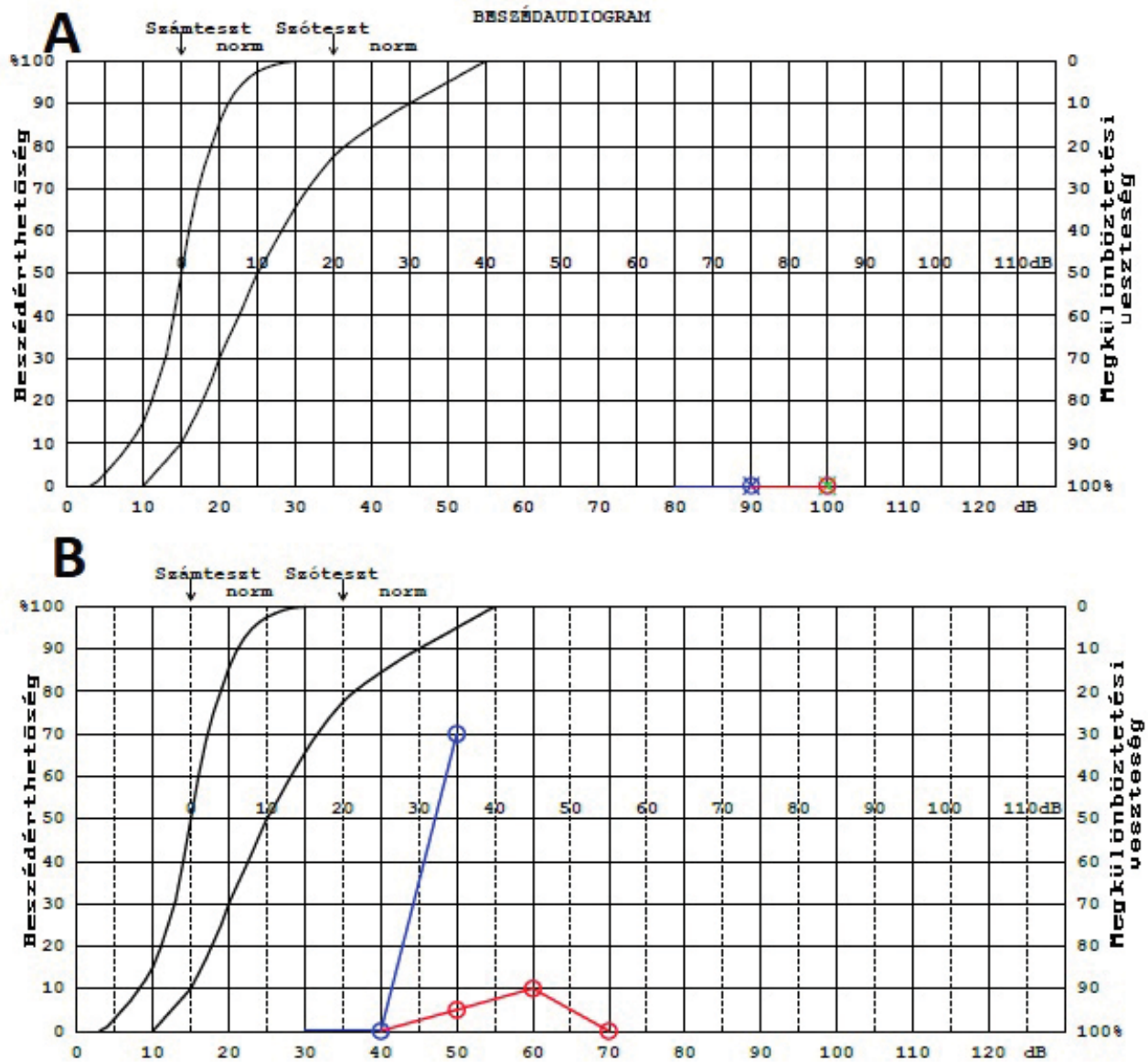

Wegener-granulomatosis esetén a halláskárosodásnak három mechanizmusa lehetséges: fülkürtelzáródás okozta savós középfülgyulladás, a középfül üregrendszerét roncsoló granulomatosus gyulladás, illetve a cochlea ereinek gyulladása lévén sensorineuralis halláscsökkenés [11]. Amennyiben az alapbetegség remisszióba kerülése mellett sem látható hallásjavulás, úgy a beteg alkalmas lehet cochlearis implantációra. Abou-Elbmd és mtsai sikeresen végeztek cochlearis implantációt Wegener-granulomatosis talaján kialakult siketség esetében. Konklúziójuk szerint a megfelelően kezelt, remisszióban lévő betegség nem jelenti a cochlearis implantáció kontraindikációját [12]. Tagboto és mtsai egy olyan Wegener-granulomatosisban szenvedő betegnél végeztek sikeres cochlearis implantációt, akinek az amikacinnal kezelt, Mycobacterium abscessus okozta elhúzódó pulmonalis infekció mellett az alapbetegség talaján kialakult siketségét rehabilitálták [13]. Elmas munkacsoportja esetünkhöz hasonlóan, a recidiváló középfülgyulladások hátterében igazolt Wegener-granulomatosis kapcsán az infekció veszélye miatt végzett subtotalis petrosectomiát. A szerzők az aktív fertőzés hiányában egy ülésben végezték el a cochlearis implantációt, mellyel sikeresen rehabilitálták a beteg hallását [14].
A modern fülsebészeti módszerekkel ma már a korábban nehezen szanálható, a sziklacsontot érintő krónikus betegségek hatékonyan és hosszú távon kezelhetők. A többszöri tympanoplastica ellenére fennálló krónikus gennyes középfülgyulladás, a középfüldaganatok egyes típusai, a sziklacsontot érintő granulomatosus betegségek, traumák stabil megoldását jelentő subtotalis petrosectomia egyre inkább elterjed a felkészült fülsebészek között. A műtét előtt, illetve a szanációt követően kialakult halláscsökkenések az implantálható hallásjavító készülékek széles tárházával sikerrel rehabilitálhatók.

\section{Következtetés}

Közleményünkben a Wegener-granulomatosishoz társult, konzervatív kezelésre rezisztens granulomatosus középfülgyulladás és az ebből következő komplikációk modern fülsebészeti megoldását mutattuk be. Fontos hangsúlyozni, hogy a szokatlan klinikai kép hátterében gondolni kell immunológiai kórképekre, és javasolt mihamarabbi célzott vizsgálatok indikálása, továbbá a megfelelő kezelési eredmény eléréséhez elengedhetetlen a szakmák közötti kommunikáció, a mihamarabbi im- 
munszuppresszív kezelés megkezdése, valamint - ahogy esetünkben is - a legújabb mütéti technikák és hallásrehabilitációs lehetőségek ismerete.

Anyagi támogatás: A szerzők anyagi támogatásban nem részesültek.

Szerzői munkamegosztás: T. I.: Levelező szerző, a kézirat szerkesztője. R. P.: Lektor, a bemutatott beteg kezelőorvosa. K. B.: A szövettani minta véleményezóje. H. G.: A beteg kezelésében részt vevő immunológus. P. Z., B. P., L. L.: A beteg kezelésének résztvevői. G. I.: A közlemény lektora. A szerzők a cikk végleges változatát elolvasták és jóváhagyták.

Érdekeltségek: A szerzőknek nincsenek érdekeltségeik.

\section{Köszönetnyilvánítás}

A szerzők köszönetüket fejezik ki a Pécsi Tudományegyetem Radiológiai Klinika munkatársainak a publikációban megjelent radiológiai képanyag elkészítéséért és leletezéséért.

\section{Irodalom}

[1] Relle M, Föhr B, Fasola F, et al. Genetics and pathophysiology of granulomatosis with polyangiitis (GPA) and its main autoantigen proteinase 3. Mol Cell Probes 2016; 30: 366-373.

[2] Yoshida N, Iino Y. Pathogenesis and diagnosis of otitis media with ANCA-associated vasculitis. Allergol Int. 2014; 63: 523532.

[3] Lutalo PM, D'Cruz DP. Diagnosis and classification of granulomatosis with polyangiitis (aka Wegener's granulomatosis). J Autoimmun. 2014; 48-49: 94-98.

[4] Harabuchi Y, Kishibe K, Tateyama K, et al. Clinical features and treatment outcomes of otitis media with antineutrophil cytoplasmic antibody (ANCA)-associated vasculitis (OMAAV): a retro- spective analysis of 235 patients from a nationwide survey in Japan. Mod Rheumatol. 2017; 27: 87-94.

[5] Del Pero MM, Chaudhry A, Rasmussen N, et al. A disease activity score for ENT involvement in granulomatosis with polyangiitis (Wegener's). Laryngoscope 2013; 123: 622-628.

[6] Safavi Naini A, Ghorbani J, Montazer Lotfe Elahi S, et al. Otologic manifestations and progression in patients with Wegener's granulomatosis: a survey in $\mathbf{5 5}$ patients. Iran J Otorhinolaryngol. 2017; 29: 327-331.

[7] Szymański M, Ataide A, Linder T. The use of subtotal petrosec tomy in cochlear implant candidates with chronic otitis media. Eur Arch Otorhinolaryngol. 2016; 273: 363-370.

[8] Coker NJ, Jenkins HA, Fisch U. Obliteration of the middle ear and mastoid cleft in subtotal petrosectomy: indications, technique, and results. Ann Otol Rhinol Laryngol. 1986; 95: 5-11.

[9] Prasad SC, Roustan V, Piras G, et al. Subtotal petrosectomy: surgical technique, indications, outcomes, and comprehensive review of literature. Laryngoscope 2017; 127: 2833-2842.

[10] Patel PK, von Keudell A, Moroder P, et al. Recurrent septic arthritis due to Achromobacter xylosoxidans in a patient with granulomatosis with polyangiitis. Open Forum Infect Dis. 2015; 2: ofvl 145 .

[11] McDonald TJ, DeRemee RA, Weiland LH. Wegener's granulomatosis and polymorphic reticulosis - two diseases or one? Experience with 90 patients. Arch Otolaryngol. 1981; 107: 141-144.

[12] Abou-Elhmd KA, Hawthorne MR, Flood LM. Cochlear implantation in a case of Wegener's granulomatosis. J Laryngol Otol. 1996; 110: 958-961.

[13] Tagboto SK, Venkatesh AG. Progressive dyspnoea following the treatment of Mycobacterium abscessus infection in an individual with relapsing granulomatosis with polyangiitis (Wegener's), complicated by hearing loss requiring cochlear implantation. BMC Pulm Med. 2012; 12: 47.

[14] Elmas F, Shrestha BL, Linder TE. Subtotal petrosectomy and cochlear implant placement in otologic presentation of "Wegener's granulomatosis". Kathmandu Univ Med J. 2017; 15: 93-98.

(Tóth István dr., Pécs, Munkácsy M. u. 2., 7621 e-mail: drtoth.i7@gmail.com)

\title{
Felhívás előfizetésre
}

\author{
Legyen Olvasónk a következő évben is! \\ Fizessen elő az Orvosi Hetilap 2019-es évfolyamára! \\ Egy füzet ára: $1150 \mathrm{Ft}$. \\ Éves előfizetési díj: $49900 \mathrm{Ft}$, nyugdijasoknak: $39990 \mathrm{Ft}$. \\ Az online változat éves előfizetési dija: $29990 \mathrm{Ft}$.
}

A cikk a Creative Commons Attribution 4.0 International License (https://creativecommons.org/licenses/by/4.0/) feltételei szerint publikált Open Access közlemény, melynek szellemében a cikk bármilyen médiumban szabadon felhasználható, megosztható és újraközölhető, feltéve, hogy az eredeti szerző és a közlés helye, illetve a CC License linkje és az esetlegesen végrehajtott módosítások feltüntetésre kerülnek. (SID_1) 